\title{
SYNTHESIS AND CHARACTERIZATION OF PH-SENSITIVE SACCHARIDE MODIFIED POLYURETHANE HYDROGELS - EFFECT OF POLYOL, CROSSLINKER AND ACID CHAIN EXTENDER
}

\author{
Marija Kostić ${ }^{1,3^{*}}$, Suzana Cakić2 ${ }^{2}$ Ivan Ristić ${ }^{3}$ Milena Marinović-Cincović ${ }^{4}$ \\ Ljubiša Nikolić ${ }^{2}$ Suzana Samaržija-Jovanović ${ }^{1}$

\footnotetext{
${ }^{1}$ Faculty of Sciences, University of Priština-Kosovska Mitrovica, Lole Ribara 29, 38220 Kosovska Mitrovica, Republic of Serbia

${ }^{2}$ Faculty of Technology, University of Niš, Bulevar Oslobodjenja, 16000 Leskovac, Republic of Serbia

${ }^{3}$ Faculty of Technology, University of Novi Sad, Bulevar Cara Lazara 1, 21000 Novi Sad, Republic of Serbia

${ }^{4}$ Institute of Nuclear Science Vinča, University of Belgrade, Mike Petrovića Alasa 12-14, 1100 Belgrade, Republic of Serbia
}

Biodegradable polyurethanes can be the basis for drug delivery systems that are sensitive to external changes. pH-sensitive polyurethanes (PUs) have been used successfully as intravaginal rings and specific drug delivery systems for the colon. In this study, a series of $\mathrm{pH}$-sensitive polyurethane hydrogels with a change of the polyol component (poly(ethylene glycol) 400/poly(propylene glycol) 2000/poly(ethylene glycol)-block-poly(propylene glycol)-block-poly(ethylene glycol) 1100), saccharides as crosslinkers (melibiose/raffinose/starch) and a-hydroxy carboxylic acids as chain extenders (dimethylol propionic acid/lactic acid) were synthesized. Structural characterization of the synthesized polyurethane hydrogels was performed using Fourier transform infrared spectroscopy (FTIR), which showed that the polyurethane synthesis reaction was achieved with successful crosslinking with saccharides and, despite the change of starting components, FTIR spectra for all investigated samples are almost identical. The degree of swelling of the hydrogels was monitored at $25^{\circ} \mathrm{C}$ in solutions of $\mathrm{pH}$ values 4.5 and 7.4. In samples with the polyol component block1100, the degree of swelling at $\mathrm{pH} 7.4(16.09 \%)$ was up to 9 times higher than at $\mathrm{pH} 4.5(1.82 \%)$. The effects of variable parameters on the thermal properties and phase transitions of PUs hydrogels were investigated by thermogravimetric analysis (TGA) and differential scanning calorimetry (DSC). The results showed that by varying the saccharide as a crosslinker, the acid chain extender and the chain length of the polyols, the stated properties of polyurethane hydrogels as potential drug delivery carriers can be influenced.
(ORIGINAL SCIENTIFIC PAPER)
UDC 678.664:543.2

DOI 10.5937/savteh2101029K

Keywords: Polyurethane, $\mathrm{pH}$ sensitivity saccharide, drug delivery system

\section{Introduction}

Hydrogels or hydrophilic hydrogels are highly elastic materials consisting of three-dimensionally cross-linked hydrophilic polymers, which show the ability to absorb large amounts of water or biological fluids, whereby they swell but do not dissolve. Different types of hydrogels developed in recent decades have become the materials of choice for many applications. Using appropriate monomers and building blocks, it is possible to obtain hydrogels that change their properties in response to changes in stimuli from the external environment, such as changes in temperature, $\mathrm{pH}$, ionic strength of the solution, pressure, light, electric and magnetic fields. The ability of special types of hydrogels to give the desired response to changing environmental conditions classifies them as "intelligent materials" [1-3].

Polyols and isocyanates are the main raw materials for the production of polyurethanes. However, the addition of certain additives can significantly contribute to their final properties. Carbohydrates have been widely used as the additives in the production of Pus, mainly due to their structural compatibility and non-toxicity. Having in mind the protection of the environment and structural compatibility, carbohydrates have been used in many studies as mentioned additives for PUs [4-10]. Naturally distributed carbohydrates such as starch, cellulose, chitosan and alginate are being increasingly used as biomaterials, since they are non-toxic, biodegradable, biocompatible and can be derived from the renewable sources. The lack of good thermal properties, poor solubility and difficult processing, are serious limitations of polyurethanes. However. the addition of carbohydrates in the structure of polyurethane can result in obtaining biodegradable materials with synergistic properties with improved mechanical and thermal properties [11]. After conducted studies on the biocompatibility of polyurethanes cross-linked with carbohydrates, Solanski et al.

\footnotetext{
*Author address: Marija Kostić, Faculty of Sciences, University of Priština-Kosovska Mitrovica Lole Ribara 29, 38220 Kosovska Mitrovica, Republic of Serbia

e-mail: marija.kostic@pr.ac.rs mkostic607@gmail.com

The manuscript received: March, 18, 2020.

Paper accepted: April, 27, 2021.
} 
[9] investigated the modification of these polyurethanes using acids as chain extenders, to obtain $\mathrm{pH}$-sensitive polyurethanes, due to their significant application. In the field of polyurethane, only a few studies are available where such research has been conducted.

Today, PUs are increasingly used as carriers of drugs in the field of medical sciences [12]. Increasing interest has been attracted by drug delivery systems that are sensitive to external changes and are based on biodegradable polyurethanes [13]. $\mathrm{pH}$-sensitive polyurethanes have been used successfully as intravaginal rings [14] and specific colon drug delivery systems $[15,16]$. One of the main advantages of polyurethanes for this application is their flexible chemical structure. A simple modification of the stoichiometry and/or raw materials used for the PU synthesis can result in a significant change in the properties of the final polymer [17]. Solanki et al. [10] concluded that the release rate of the active substance is directly proportional to the polyol/crosslinker and polyol/chain extender ratio, and inversely proportional to the $\mathrm{NCO} / \mathrm{OH}$ ratio. These results show that the control of the structural design of the PU can enable the control of drug release from the polyurethane matrix.

The goal of this study was to investigate the influence of the chain length of the polyol component, saccharides as crosslinkers and acids as chain extenders on the properties of $\mathrm{pH}$-sensitive polyurethane hydrogels as potential carriers of medicinal substances.

\section{Experimental}

\section{Reagents:}

Hexamethylene-diisocyanate (HMDI) (Fluka Analytical, Buchs, Switzerland), polyethylene glycol 400 (PEG400), poly(ethylene glycol)-block-poly(propylene glycol)-block-poly(ethylene glycol) 1100 (PEG-PPGPEG 1100), polypropylene glycol 2000 (PPG2000), dibutyltin dilaurate (DBTDL), triethylamine (TEA) and dimethylolpropionic acid (DMPA) are from Sigma Aldrich, St. Louis, USA, lactic acid, melibiose hydrate (Reanal), raffinose 5-hydrate (Acros Organics, New Jersey SAD), starch (Centrohem d.o.o., Stara Pazova, Serbia), tetrahydrofuran (THF) (Zdravlje AD, Leskovac, Serbia).

All the other materials and solvents used for analytical methods were of analytical grade.

\section{Synthesis of hydrogels:}

In a three-necked balloon, equipped with a stirrer, water condenser and a thermometer, $3 \mathrm{~g}$ of the polyol component was added. The appropriate stoichiometric amount of HMDI was added drop-wise over a time interval of $15 \mathrm{~min}$. The reaction was allowed to proceed at $70{ }^{\circ} \mathrm{C}$ for $2 \mathrm{~h}$. A certain crosslinker was dispersed in THF and then added drop-wise to the reaction balloon. After stirring for $2 \mathrm{~h}$ at $70{ }^{\circ} \mathrm{C}$, the calculated amount of acid chain extender and catalyst, DBTDL, was added, and stirring was continued for another 1 hour at $70^{\circ} \mathrm{C}$. After the specified time, the mixture was allowed to cool to room temperature. The calculated amount of TEA was then added to neutralize the carboxyl groups and stirring was continued for another $30 \mathrm{~min}$ at $25^{\circ} \mathrm{C}$. During the synthesis, THF was optionally added as needed to regulate the viscosity. The obtained dispersion was added, drop by drop, to $60 \mathrm{ml}$ of distilled water. To obtain plateshaped polyurethanes, the synthesized samples were poured into glass molds. After a few days of drying at room temperature, glass molds were kept in a vacuum oven at $60{ }^{\circ} \mathrm{C}$ for $24 \mathrm{~h}$. In all samples, the mole ratio polyol/diisocyanate/crosslinker acid chain extender was kept as $1 / 2.7 / 0.5 / 1$. The synthesis procedure is represented by the scheme shown in Figure 1. The labels of the obtained hydrogels and the components used for their synthesis are shown in Table 1.

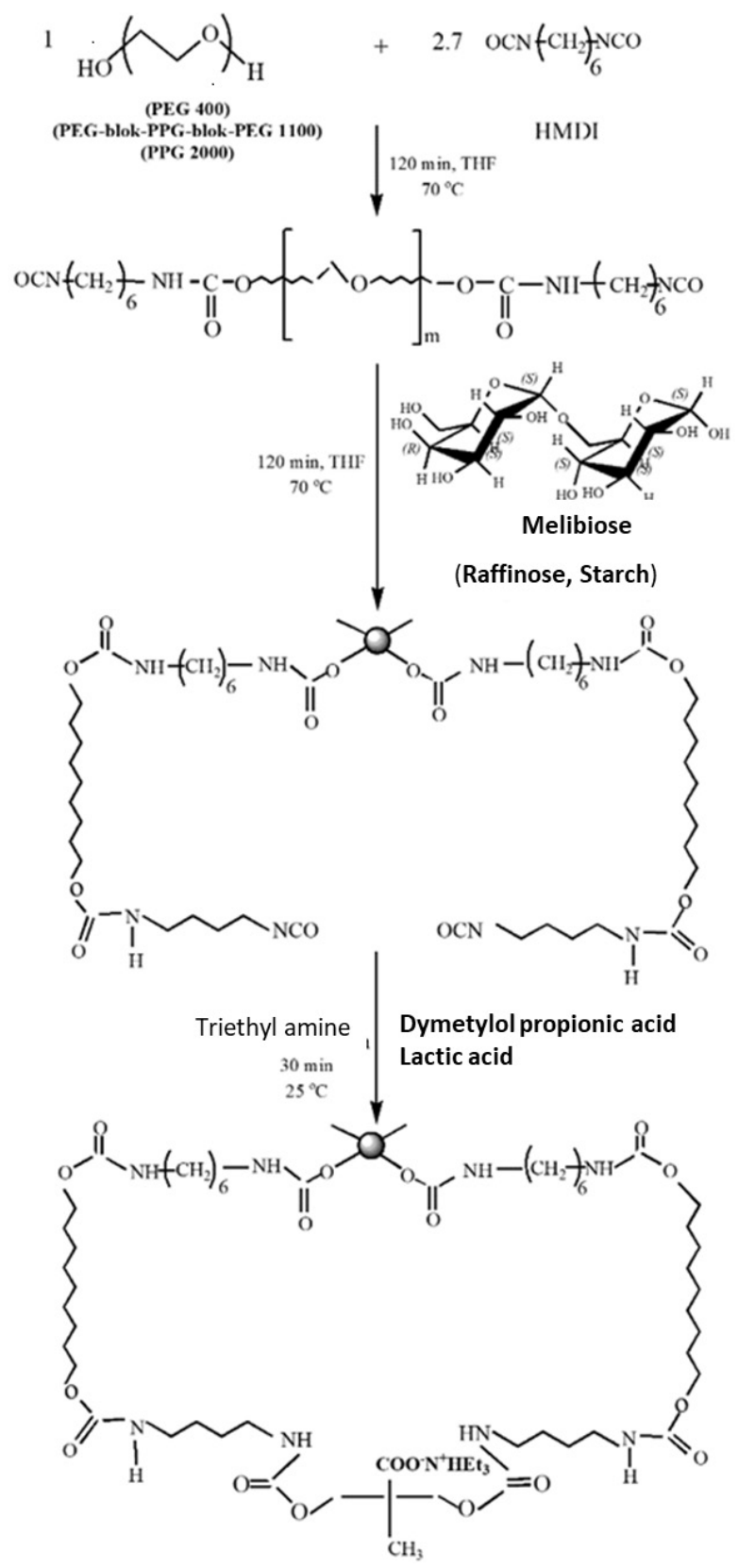

Figure 1. Scheme of synthesis of $\mathrm{pH}$-sensitive carbohydrate crosslinked biocompatible polyurethanes 
Table 1. Label and composition of synthesized carbohydrate crosslinked biocompatible polyurethane hydrogels

\begin{tabular}{ccccccc}
\hline $\begin{array}{c}\text { Hydrogel } \\
\text { label }\end{array}$ & Polyol & $\begin{array}{c}\text { Amount } \\
\text { of } \\
\text { polyol }\end{array}$ & Crosslinker & $\begin{array}{c}\text { Amount of } \\
\text { crosslinker }\end{array}$ & $\begin{array}{c}\text { Chain } \\
\text { extender }\end{array}$ & $\begin{array}{c}\text { Amount of } \\
\text { chain } \\
\text { extender }\end{array}$ \\
\hline PEG400RD & PEG 400 & $3,000 \mathrm{~g}$ & Raffinose & $2,626 \mathrm{~g}$ & DMPA & $1,006 \mathrm{~g}$ \\
PEG400RM & PEG 400 & $3,000 \mathrm{~g}$ & Raffinose & $2,626 \mathrm{~g}$ & Lactic acid & $0,56 \mathrm{ml}$ \\
PPG2000MD & PPG 2000 & $2,98 \mathrm{ml}$ & Melibiose & $0,28 \mathrm{~g}$ & DMPA & $0,2 \mathrm{~g}$ \\
Blok-1100MD & PPG-PEG-PPG 1100 & $2,94 \mathrm{ml}$ & Melibiose & $0,504 \mathrm{~g}$ & DMPA & $0,366 \mathrm{~g}$ \\
PPG2000SD & PPG 2000 & $2,98 \mathrm{ml}$ & Starch & $0,121 \mathrm{~g}$ & DMPA & $0,2 \mathrm{~g}$ \\
Blok-1100SM & PPG-PEG-PPG 1100 & $2,94 \mathrm{ml}$ & Starch & $0,221 \mathrm{~g}$ & Lactic acid & $0,2 \mathrm{ml}$ \\
\hline
\end{tabular}

Fourier transform infrared spectrometry: To examine the chemical structure of the synthesized samples, FTIR spectres were recorded using the technique of thin transparent tablets with potassium bromide of spectroscopic purity, by vacuuming and pressing under a pressure of about $200 \mathrm{MPa}$. $150 \mathrm{mg}$ of $\mathrm{KBr}$ and $1 \mathrm{mg}$ of samples were weighed to prepare tablets. Recording was performed in the range of wave numbers from 4000 to $500 \mathrm{~cm}^{-1}$ on an FTIR spectrophotometer Bomem Hartmann \& Braun MBseries. The spectra were processed using Win-Bomem Easy software.

Thermogravimetric analysis: Thermal stability was determined by non-isothermal thermogravimetry (TG) using a Setaram Setsys Evolution 1750 instrument (France). The samples were heated in the temperature range from 30 to $800{ }^{\circ} \mathrm{C}$ in an argon atmosphere with a heating rate of $10^{\circ} \mathrm{C} / \mathrm{min}$.

Differential calorimetry scanning: Differential scanning calorimeter Q100, was used to examine the phase transitions of the obtained samples. The flow of inert gas (nitrogen) during the test was $30-40 \mathrm{~cm}^{3} / \mathrm{min}$. The measurement was performed in the temperature range from -100 to $100{ }^{\circ} \mathrm{C}$, at a heating rate of $10^{\circ} \mathrm{C} / \mathrm{min}$. Standard calibration of the instrument was performed using indium $\left(\mathrm{Tm}=156.6^{\circ} \mathrm{C}\right)$. DSC thermograms were processed using TA Universal Analysis software.

Swelling behavior: Liquids with different $\mathrm{pH}$ values: 4.5 and 7.4 at a temperature of $25^{\circ} \mathrm{C}$ were used to determine the degree of swelling of polyurethane hydrogels. After measuring the mass, the samples were immersed in the solutions, and then the swelling was monitored gravimetrically. At certain time intervals, samples were taken from the solution and measured until equilibrium i.e. constant masses were reached. $\mathrm{KH}_{2} \mathrm{PO}_{4}, \mathrm{Na}_{2} \mathrm{HPO}_{4}$, $\mathrm{NaCl}$ and distilled water were used to prepare buffer solutions with $\mathrm{pH}$ values 4.5 and 7.4 following the instructions given in methods 4009000 and 4004600 described in Eur. Ph. 7.0 [18]. The swelling degree, Q, was calculated with the equation (1):

$$
Q=\frac{m-m_{0}}{m_{0}} \cdot 100
$$

where is $m_{0}-$ xerogel mass, and $m_{1}$ - mass of the swollen hydrogel.

\section{Results and discussion}

The same diisocyanate was used in all syntheses, and the individually used polyol components, saccharide crosslinkers, and acid chain extenders were structurally similar, so the FTIR spectra of all samples were almost identical. The FTIR spectra of PEG400RD, PEG400RM, blok1100MD and blok1100SM hydrogels are presented in this study (Figure 2). At the wave number of $2270 \mathrm{~cm}^{-1}$ on the FTIR spectra of all tested samples, no peak corresponding to the NCO group was observed, which is a confirmation that all isocyanate groups reacted with hydroxyl groups of saccharides during the synthesis. Confirmation of the crosslinking reaction is the existence of appropriate vibrations for the urethane group, $\mathrm{NH}-\mathrm{CO}-\mathrm{O}$. These are the streching vibration of the hydrogen-bound $-\mathrm{NH}$ group at $3330-3360 \mathrm{~cm}^{-1}$, and the bending vibration of the C-O at $1620-1688 \mathrm{~cm}^{-1}$. The absorption maximum occurring at $2934 \mathrm{~cm}^{-1}$ corresponds to the streching vibrations of the $\mathrm{C}-\mathrm{H}$ of the methylene, $-\mathrm{CH}_{2}$, groups within the polyol segments of polyurethane. The absorption bands at $1700-1710 \mathrm{~cm}^{-1}$ could be assigned to a carbonyl group for hydrogen-bonded as cited by Reddy et al. [19]. The bending vibration of the $\mathrm{N}-\mathrm{H}$ from the amide group shows an absorption maximum at $1540-1560 \mathrm{~cm}^{-1}$.

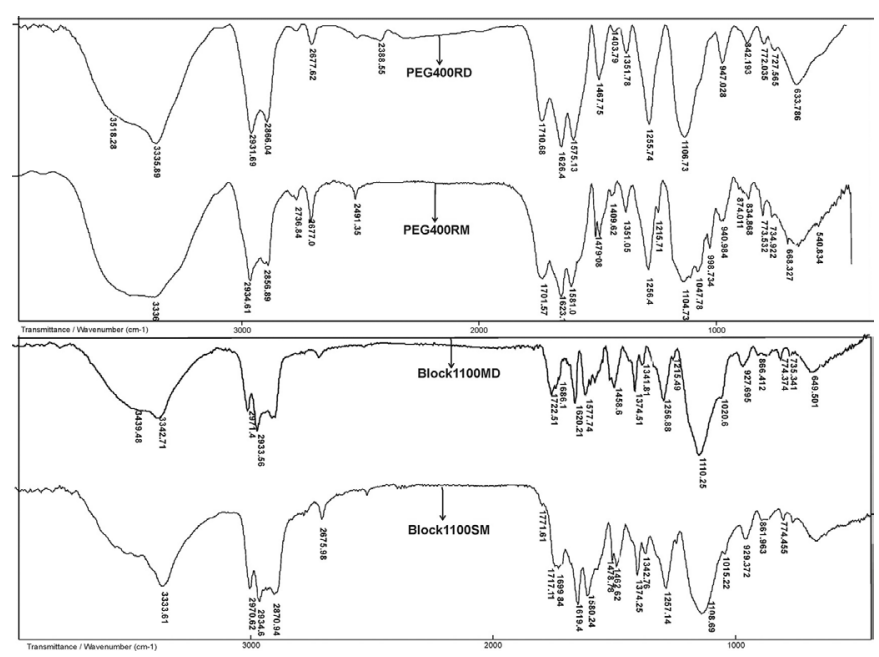

Figure 2. FTIR spectra of carbohydrate crosslinked biocompatible polyurethanes: PEG400RD, PEG400RM, blok1100MD and blok1100SM samples

Since acids were used as chain extenders, it is assumed that the $\mathrm{COOH}$ group will remain unreacted and 
a maximum absorption corresponding to it should be obtained. The maximum absorption at $1670-1680 \mathrm{~cm}^{-1}$ corresponding to the $\mathrm{C}=\mathrm{O}$ group of acids and shoulder peak at around $3500 \mathrm{~cm}^{-1}$ which could arise due to the $\mathrm{OH}$ group of acids confirms the presence of acid group supporting the above hypothesis. By explaining the characteristic peaks from the obtained FTIR spectra, it can be concluded that synthesized hydrogels have a chemical structure that corresponds to the scheme shown in Figure 2.

Figure 3 shows comparative DSC thermograms of samples PEG400RM and PEG400RD, PPG2000MD and PPG2000SD, PPG2000MD and block1100MD, respectively. The exothermic peaks on the DSC thermogram are at lower temperatures (below $0{ }^{\circ} \mathrm{C}$ ) corresponding to the glass transition temperature of the soft segments $\left(\operatorname{Tg}_{\mathrm{sS}}\right)$.

The DSC thermogram in Figure 3a shows the influence of the acid chain extender on the value of $\mathrm{Tg}_{\mathrm{ss}}$ of the polyurethane hydrogels. The sample with lactic acid as a chain extender has a higher $\operatorname{Tg}_{\text {SS }}\left(-26.29^{\circ} \mathrm{C}\right)$ than the sample with DMPA $\left(-28.65^{\circ} \mathrm{C}\right)$. This can be explained by the fact that $\mathrm{Tg}$ largely depends on molecular mobility. PUs with a highly crosslinked structure have less chain mobility resulting in higher Tg. Although the reactivity of the NCO groups to the primary hydroxyl group is about 3.3 times higher than to the secondary [20], it is assumed that the lower degree of crosslinking in the sample with DMPA is due to the steric disorders caused by both hydroxyl groups. Therefore, the above $\mathrm{Tg}_{\mathrm{SS}}$ findings could be explained based on the structureproperty relationship, which is explained above.

The effect of saccharides as crosslinkers on TgSS of the polyurethane hydrogels can be seen from the thermogram in Figure $3 b$. It is obvious that the sample with starch as a crosslinker, which is a polysaccharide and has a larger number of $\mathrm{OH}$ groups that can react with NCO groups, will have a more crosslinked structure compared to the sample which contains a monosaccharide as a crosslinker or a disaccharide (melibiose). $\mathrm{Tg}_{\mathrm{ss}}$ directly depends on the degree of crosslinking, ie chain mobility, which is the reason for the higher value of $\mathrm{Tg}_{\mathrm{SS}}$ of the PPG2000SD sample, compared to PPG2000MD.

Figure $3 c$ shows the effect of polyol chain length on the $\mathrm{Tg}_{\mathrm{SS}}$ value of polyurethane hydrogels. Although both polyols are linear in structure, PPG-PEG-PPG 1100 has a shorter chain compared to PPG 2000. Due to the shorter chain, the crosslinking density increases, resulting in a polyurethane hydrogel with less chain flexibility. Due to the limited movements of the chains, which reduces the mobility, the value of $\mathrm{Tg}$ increases. On the other hand, the lower values for $\mathrm{Tg}$ in the PPG 2000 polyol can be explained based on its structure. Numerous $-\mathrm{CH}_{2}$ groups in the structure of the PPG 2000 polyol, due to its higher molecular weight than PPG-PEG-PPG 1100, contribute to the flexibility of the formed network [7]. An additional explanation for the lower crosslinking density of PPG 2000 polyols is the side methyl group that causes steric interference [21].
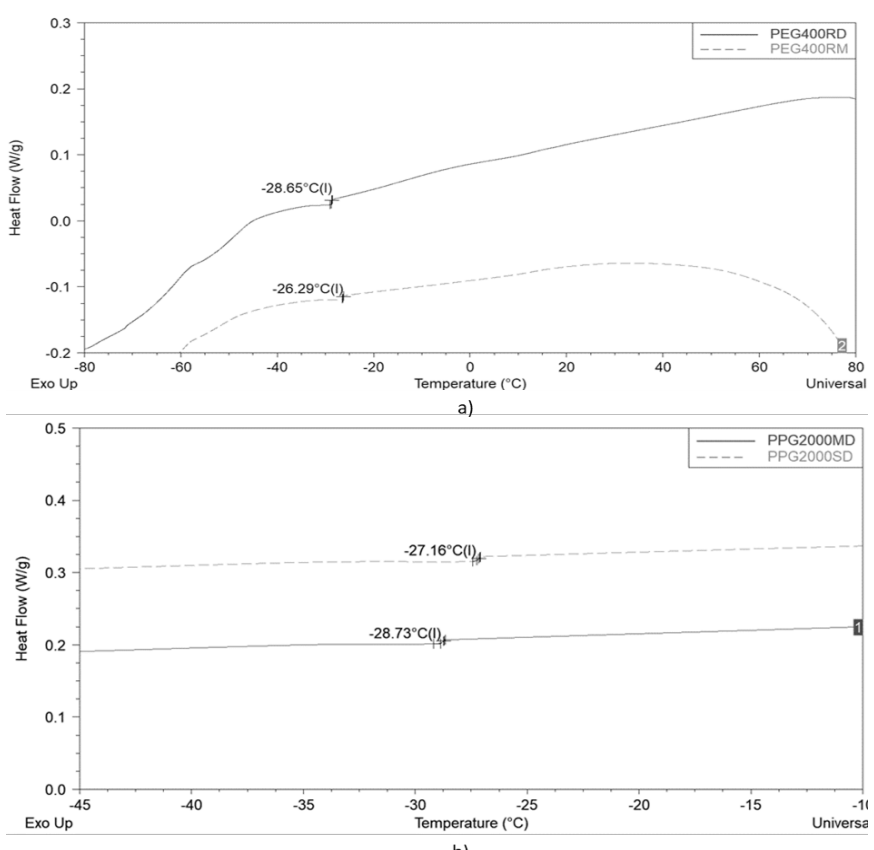

b)

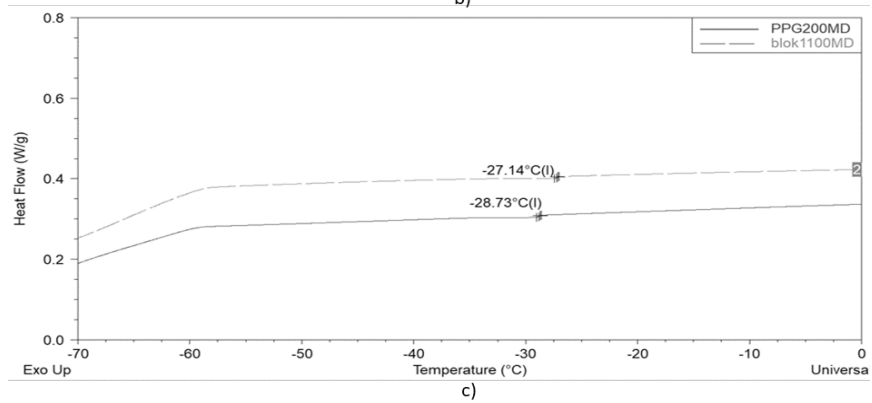

Figure 3. DSC spectra of synthesized carbohydrate crosslinked biocompatible polyurethanes and effect of a) acid chain extender, b) crosslinker and c) polyol component on $\mathrm{Tg}_{\mathrm{sS}}$

In the study of Solanki et al. [7], it was proved that despite the use of saccharides that have low thermal stability, polyurethanes crosslinked with them show reasonable thermal stability. The TG curve of the synthesized hydrogels (Figure 4) showed an initial mass loss at temperatures of $101-205^{\circ} \mathrm{C}$. The observed mass loss could be attributed to the loss of volatile contents, such as water. Despite the lower thermal stability of saccharides, all analyzed samples showed good thermal stability up to $200{ }^{\circ} \mathrm{C}$. Mass loss in the temperature range of 200 to $390{ }^{\circ} \mathrm{C}$ may be associated with the degradation of hard segments [10]. Subsequent degradation has been attributed to the degradation of amide bonds which, according to Rueda-Larraz et al. [17], may result in dissociation into isocyanates and alcohols, formation of a secondary amine and carbon dioxide, or formation of a primary amine and olefin. 


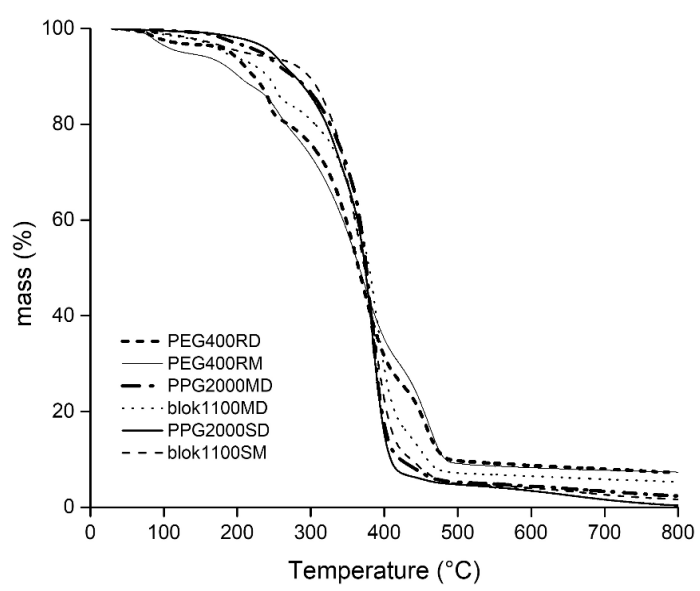

Figure 4. TG curves of synthesized carbohydrate crosslinked biocompatible polyurethanes
The use of different acid chain extenders did not lead to a significant difference in thermal stability. In the Figure 5a showing the comparative TG curves of the PEG400RD and PEG400RM samples, it can be seen that the samples behaved similarly towards degradation as a function of temperature. The presented comparative derivative thermogravimetry (DTG) curves confirm this, where it is observed that the maximum degradation is at approximate temperatures. Figure $5 \mathrm{~b}$ shows comparative TG and DTG curves for two samples with different saccharide crosslinkers, PPG2000SD and PPG2000MD. The degradation pattern is similar for both crosslinkers, suggesting that the thermal stability of the synthesized polyurethanes is independent of the crosslinker type. In the Figure $5 \mathrm{c}$ showing the comparative TG and DTG curves of the PEG400RD and PPG2000MD samples, it can be seen that there is a significant difference in the thermal degradation of the samples containing polyols of different chain lengths.
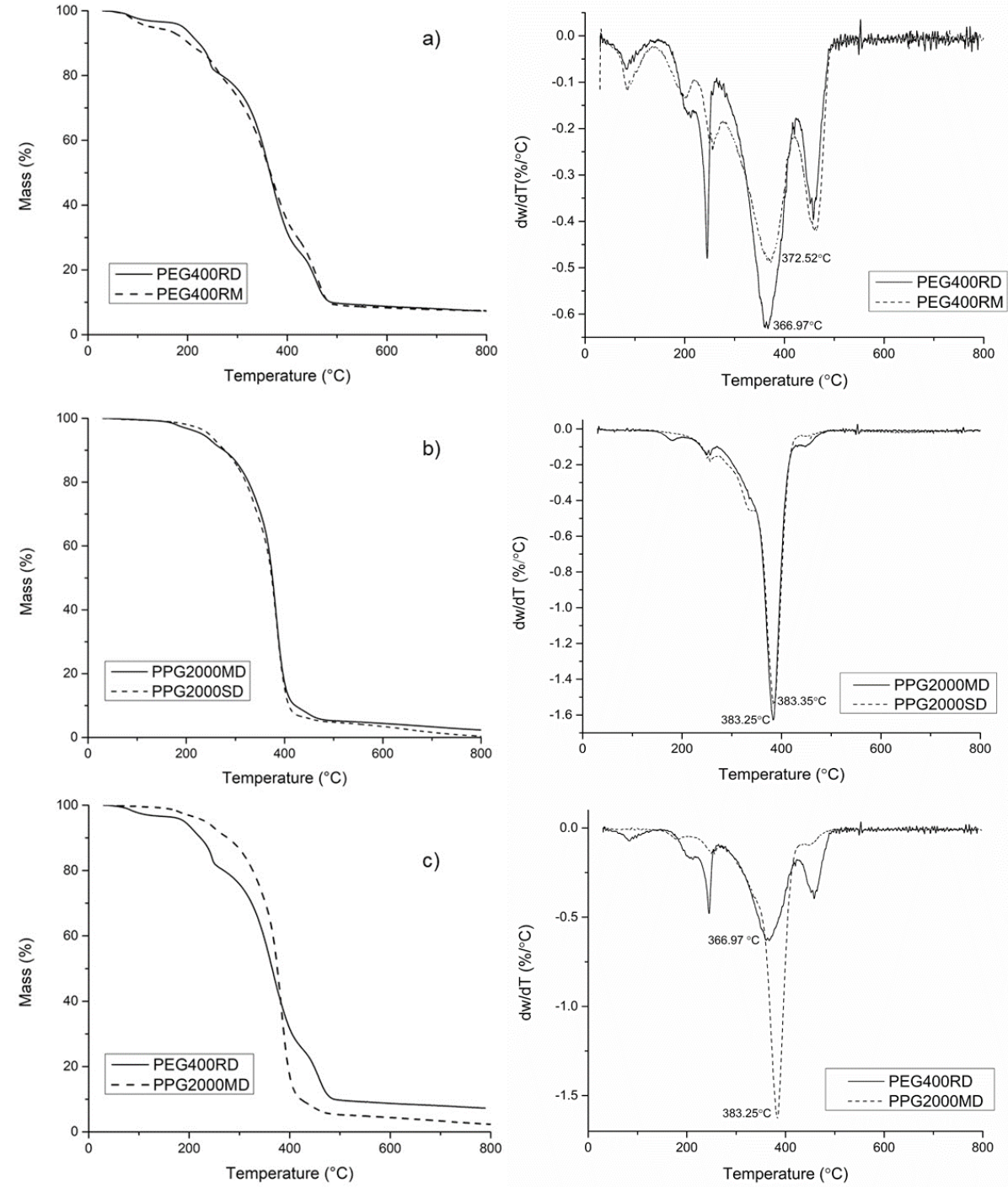

Figure 5. Influence of a) acid chain extender, b) crosslinker and c) polyol component on thermal stability of carbohydrate crosslinked biocompatible polyurethanes 
In the PPG2000MD sample, a shift in the degradation maximum relative to the PEG400RD sample was observed. The PPG2000MD sample has a maximum degradation at $383.25^{\circ} \mathrm{C}$, while the PEG400RD has a maximum at $366.97^{\circ} \mathrm{C}$. Accordingly, it can be concluded that the thermal stability of polyurethane depends on the polyol component used, more precisely on the chain length of the same, so that polyurethanes with a polyol component of shorter chain length have less thermal stability than those containing longer chain polyol.

The polyurethane hydrogels synthesized in this study contain a-hydroxy acids and are anionic polymers sensitive to the $\mathrm{pH}$ value of the medium. The degree of swelling of ionic polymers depends on several factors, such as the charge on the polymer, its concentration, crosslinking density and hydrophilicity of the polymer [22]. As these are polyurethane hydrogels with acidic groups, it is expected that at fluid with lower $\mathrm{pH}$ value, $\mathrm{pH}=4.5$, they swell to a lesser extent than at the fluid with $\mathrm{pH}$ value 7.4 , which is confirmed by the results shown in the Table 2. This is an obvious phenomenon where most of the carboxyl groups on the polymer surface remain non-ionized under acidic conditions. However, the change in $\mathrm{pH}$ leads to increased swelling of anionic polymers due to two important phenomena that occur simultaneously [23]. First, the increase in charge density due to ionized acid groups leads to large differences in cation concentration between the inner and outer surface of the polymer resulting in an increase in the osmotic pressure between the polymer and the solution. This ultimately causes easier penetration of the solution into the polymer network, which results in a higher degree of swelling. Another phenomenon is electrostatic repulsion on the polymer surface, which also enhances the expansion of polymer chains.

Table 2. Equilibrium degree of swelling of the synthesized samples at fluids with $\mathrm{pH}$ values 4.5 and 7.4

\begin{tabular}{ccc}
\hline Sample & $\mathbf{p H}=\mathbf{4 . 5}$ & $\mathbf{p H}=\mathbf{7 . 4}$ \\
\hline PEG400RD & 43.26 & 48.66 \\
PEG400RM & 18.18 & 21.91 \\
Blok1100MD & 1.82 & 16.09 \\
PPG2000SD & 1.46 & 3.32 \\
Blok1100SM & 7.81 & 25.07 \\
\hline
\end{tabular}

In a liquid with a $\mathrm{pH}$ value 4.5 , the synthesized polyurethane hydrogels should have minimum values of the degree of swelling, while in the liquid with $\mathrm{pH}$ value 7.4 , that value should be significantly higher. Such results are best shown by those polyurethane samples containing block 1100 as a polyol component. Primarily a block1100MD in which the degree of swelling at different $\mathrm{pH}$ values changed nine times. Figure 6 shows the dependence of the swelling degree on time for PUs in the solutions with different $\mathrm{pH}$ values. The highest degree of swelling in both solutions is achieved by PEG400RD. In contrast to the research of Bhattacharyya et al. [24] according to which the degree of swelling is higher with an increase in chain length increasing chain length of the polyol component, the results obtained in this paper show the opposite. One explanation for this may be that due to their hydrophilicity, saccharides offer greater compatibility with PPG which is also hydrophilic, compared to hydrophobic PEG [12].

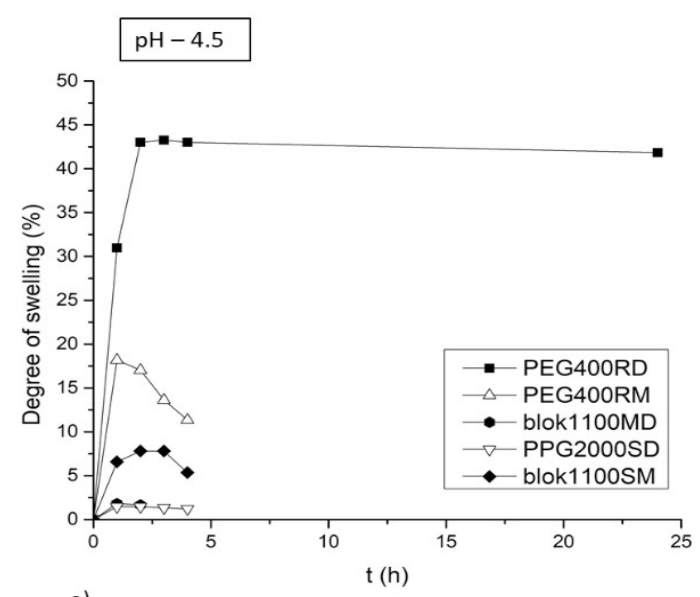

a)

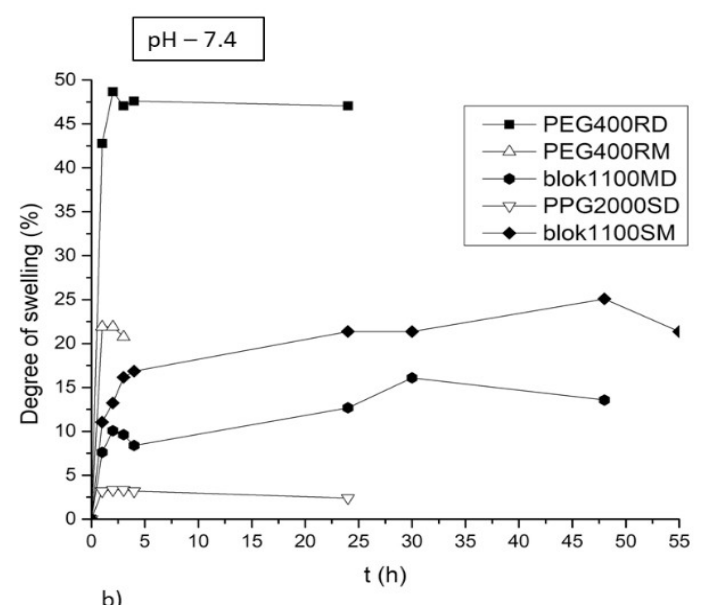

Figure 6. Dependence of the swelling degree on time for synthesized carbohydrate crosslinked biocompatible polyurethanes: a) in $\mathrm{pH} 4.5, \mathrm{~b}$ ) in $\mathrm{pH} 7.4$

\section{Conclusion}

Synthesis and characterization of a series of $\mathrm{pH}$ sensitive polyurethane hydrogels with different polyol components, saccharides as crosslinkers and a-hydroxy acids as chain extenders were performed. By explaining the characteristic peaks from the obtained FTIR spectra, it can be concluded that the polyurethane synthesis reaction was achieved with subsequent, successful crosslinking with saccharides. The change in the polyol component, in contrast to the change in the saccharide or a-hydroxy acid, leads to a difference in the thermal stability of the samples as observed by TG analysis. The DSC method proved that changes in the polyol component, crosslinkers and chain extenders affect the value of $\mathrm{Tg}_{\mathrm{ss}}$ of synthesized samples. The synthesized samples showed a higher degree of swelling at fluid with $\mathrm{pH}$ value 7.4 than at slightly acidic fluid with 4.5 at $25{ }^{\circ} \mathrm{C}$. Sam- 
ples containing block1100 as the polyol component had the best difference in swelling at different $\mathrm{pH}$ values. By varying the sugar component as a crosslinker, the acid chain extender and the chain length of the polyols, the structural properties of polyurethane hydrogels as potential carriers of therapeutic agents can be influenced. For further research on the potential pharmaceutical use of the obtained hydrogels, it is important to examine the properties of swelling in simulated physiological conditions.

\section{Acknowledgements}

The research was funded by the Ministry of Education, Science and Technological Development of the Republic of Serbia, Program for financing scientific research work, number 451-03-9/2021-14/200133.

Abbreviations and symbols

FTIR - Fourier transform infrared spectroscopy

TGA - Thermogravimetric analysis

DSC - Differential scanning calorimetry

DTG - Derivative thermogravimetry

PU - Polyurethane

HMDI - Hexamethylene-diisocyanate

PEG - Polyethylene glycol

PPG - Polyprolylene glycol

DMPA - Dimethylolpropionic acid

DBTDL - Dibutyltin dilaurate

TEA - Triethylamine

$\mathrm{Tg}_{\mathrm{SS}}$ - Glass transition temperature of the soft segments

\section{References}

[1] M.Mahkam, M. Allahverdipoor, Controlled release of biomolecules from $\mathrm{pH}$-sensitive network polymers prepared by radiation polymerization, Journal of Drug Targeting, 12 (2004) 151-156.

[2] W. Xue, S. Champ, M. Huglin, Network and swelling parameters of chemically crosslinked thermoreversible hydrogels, Polymer, 42(8) (2001) 3665-3669.

[3] J. Park, Preparation and characterization of hydrogels using biopolymers, Journal of Material Sciences and Engineering, 5 (2016) 10-48.

[4] S. Desai, I.M. Thakore, B.D. Sarawade, S. Devi, Effect of polyols and diisocyanates on thermo-mechanical and morphological properties of polyurethanes, European Polymer Journal, 36(4) (2000) 711-725.

[5] R. Lalwani, S. Desai, Sorption behavior of biodegradable polyurethanes with carbohydrate crosslinkers, Journal of Applied Polymer Science, 115 (2010) 1296-1305.

[6] M. Valodkar, S. Thakore, Isocyanate crosslinked reactive starch nanoparticles for thermo-responsive conducting applications, Carbohydrate Research, 345(16) (2010) 2354-2360.

[7] A. Solanki, J. Mehta, S. Thakore, Structure-property relationships and biocompatibility of carbohydrate crosslinked polyurethanes, Carbohydrate Polymers, 110 (2014) 338-344.
[8] A. Solanki, S. Sanghvi, R. Devkar, S. Thakore, $\beta$-Cyclodextrin based magnetic nanoconjugates for targeted drug delivery in cancer therapy, RSC Advances, 6(101) (2016) 98693-98707.

[9] A. Solanki, S. Thakore, Cellulose crosslinked pHresponsive polyurethanes for drug delivery: a-hydroxy acids as drug release modifiers, International Journal of Biological Macromolecules, 80 (2015) 683-691.

[10] A. Solanki, B. Kamath, S. Thakore, Carbohydrate crosslinked biocompatible polyurethanes: synthesis, characterization, and drug delivery studies, Journal of Applied Polymer Science, 42223(132) (2015) 1-12.

[11] A. Solanki, J. Mehta, S. Thakore, Structure-property relationships and biocompatibility of carbohydrate crosslinked polyurethanes, Carbohydrate Polymers, 110 (2014) 338-344.

[12] Y.J. Cherng, T.Y. Hou, M.F. Shih, H. Talsma, W.E. Hennink Polyurethane-based drug delivery systems. International Journal of Pharmaceutics, 450 (2013) 145-162.

[13] K. Dayananda, C. He, S. D. Lee, In situ gelling aqueous solutions of $\mathrm{pH}$ - and temperature-sensitive poly(ester amino urethane)s, Polymer, 49 (2008) 4620- 4625.

[14] M.R. Clark, T.J. Johnson, R.T. Mccabe, J.T. Clark, A Tuitupou, $\mathrm{H}$. Elgendy, A hot-melt extruded intravaginal ring for the sustained delivery of the antiretroviral microbicide. UC781, 101 (2014) 2012-2014.

[15] M. Naeem, Kim, J. Cao, Y. Jung, J. Yoo, Enzyme/pH dual sensitive polymeric nanoparticles for targeted drug delivery to the inflamed colon, Colloids and Surfaces B: Biointerfaces, 123 (2014) 271-278.

[16] T. Yamaoka, Y. Makita, H. Sasatani, S.I. Kim, Y. Kimura, Linear type azo-containing polyurethane as drugcoating material for colon-specific delivery: Its properties, degradation behavior, and utilization for drug formulation, Journal of Controlled Release, 66 (2000) 187-197.

[17] L. Rueda-larraz, B. Fernandez, A. Tercjak, A. Ribes, I. Mondragon, A. Eceiza, Synthesis and microstructuremechanical property relationships of segmented polyurethanes based on a PCL-PTHF-PCL block copolymer as soft segment, European Polymer Journal, 45 (2009) 2096-2109.

[18] European Directorate for the Quality of Medicines \& HealthCare, European Pharmacopeia $7^{\text {th }}$ ed, Council Of Europe : European Directorate for the Quality of Medicines and Healthcare, Strasbourg, 2010, p. 430-431.

[19] T.T. Reddy, A. Kano, A. Maruyama, A. Takahara, Synthesis characterization and drug release of biocompatible/ biodegradable non-toxic poly(urethane urea)s based on poly(epsilon-caprolactone)s and lysine-based diisocyanate. Journal of Biomaterials Science, Polymer Edition, 21 (2010) 1483-1502.

[20] Q.W. Lu, R.T. Hoye, W.C. Macosko, Reactivity of common functional groups with urethanes: Models for reactive compatibilization of thermoplastic polyurethane blends. J. Polym. Sci. A Polym. Chem., 40 (2002) 2310-2328.

[21] S. Gopalakrishan, L. Fernando, Influence of polyols on properties of bio-based polyurethanes, Bulletin of Materials Science, 35(2) (2012) 243-251.

[22] J.M.G. Swann, W. Bras, P.D. Topham, J.R. Howse, A.J Ryan, Effect of the Hofmeister anions upon the swelling of a self-assembled $\mathrm{pH}$-responsive hydrogel, Langmuir 26 (2010) 10191-10197.

[23] X.-F. Sun, H. Wang, Z. Jing, R. Mohanathas, Hemicellulosebased $\mathrm{pH}$-sensitive and biodegradable hydrogel for 
controlled drug delivery, Carbohydrate Polymers, 92 (2013) 1357-1366.

[24] A. Bhattacharyya, P. Mukhopadhyay, P. P. Kundu, Synthesis of a Novel pH-Sensitive Polyurethane-Alginate Blend with Poly(ethylene terephthalate) Waste for the Oral Delivery of Protein, Journal of Applied Polymer Science, 16 (2014) 131-142.

\section{Izvod \\ SINTEZA I KARAKTERIZACIJA PH-OSETLJIVIH POLIURETANSKIH HIDROGELOVA MODIFIKOVANIH SAHARIDIMA: UTICAJ POLIOLA, UMREŽIVAČA I KISELINSKOG PRODUŽIVAČA LANCA}

Marija Kostić ${ }^{1,3}$, Suzana Cakić ${ }^{2}$, Ivan Ristić ${ }^{3}$, Milena Marinović-Cincović ${ }^{4}$, Ljubiša Nikolić ${ }^{2}$, Suzana Samaržija-Jovanović ${ }^{1}$

${ }^{1}$ Prirodno-matematički fakultet, Univerzitet u Prištini-Kosovska Mitrovica, Lole Ribara 29, 38220 Kosovska Mitrovica, Republika Srbija

${ }^{2}$ Tehnološki fakultet, Univerzitet u Nišu, Bulevar oslobodjenja 16000 Leskovac, Republika Srbija

${ }^{3}$ Tehnološki fakultet, Univerzitet u Novom Sadu, Bulevar Cara Lazara 1, 21000 Novi Sad, Republika Srbija

${ }^{4}$ Institut za nuklearne nauke Vinča, Univerzitet u Beogradu, Mike Petrovića Alasa 12-14, 1100 Belgrade, Republika Srbija

Na biorazgradivim poliuretanima mogu se zasnivati sistemi za isporuku lekova osetljivi na spoljašnje promene. pH osetljivi poliuretani uspešno se koriste kao intravaginalni prstenovi i specifični sistemi za isporuku lekova za debelo crevo. $U$ ovom radu izvršena je sinteza serije $\mathrm{pH}$-osetljivih poliuretnaskih hidrogelova uz promenu poliolne komponente (poli(etilen-glikol) 400/poli(propilen-glikol) 2000/poli(etilen glikol)-blok-poli(propilen glikol)-blok-poli(etilen glikol) 1100), saharida kao umreživača (melibioza/rafinoza/skrob) i a-hidroksi karboksilnih kiselina kao produživača lanca (dimetilol propionska kiselina/mlečna kiselina). Strukturna karakterizacija sintetisanih poliretanskih hidrogelova vršena je pomoću infracrvene spektroskopije sa Furijeovom transformacijom (FTIR), čime je pokazano da je postignuta reakcija sinteze poliuretana uz uspešno umrežavanje saharidima i da su, uprkos menjanju polaznih komponenti, dobijeni FTIR spektri skoro identični. Stepen bubrenja hidrogelova posmatran je na $25^{\circ} \mathrm{C}$ u rastvorima čije su pH vrednosti 4,5 i 7,4. Kod uzoraka sa poliolnom komponentom blok1100 stepen bubrenja u rastvoru pri pH 7,4 (16,09\%) bio je i do 9 puta veći nego u rastvoru pri pH 4,5 (1,82\%). Uticaji promenjivih parametara na termička svojstva i fazne prelaze PU hidrogelova ispitivani su termogravimetrijskom analizom (TGA) i diferencijalnom skenirajućom kalorimetrijom (DSC). Rezultati su pokazali da variranjem šećerne komponente kao umreživača, kiselinskog produživača lanca i dužine lanaca upotrebljenih poliola može se uticati na navedena svojstva poliuretanskih hidrogelova kao potencijalnih nosača terapeutskih sredstava.
(ORIGINALNI NAUČNI RAD) UDK 678.664:543.2

DOI 10.5937/savteh2101029K 